\title{
Penggunaan Berbagai Sumber Karbohidrat Terlarut Air untuk Meningkatkan Kualitas Silase Daun Rami
}

\author{
Addition of Water Soluble Carbohydrate Sources Prior to Ensilage for \\ Ramie Leaves Silage Qualities Improvement
}

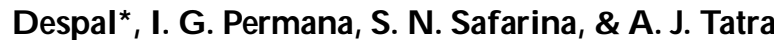 \\ Departemen Ilmu Nutrisi dan Teknologi Pakan, Fakultas Peternakan, Institut Pertanian Bogor \\ Jln. Agatis, Kampus IPB Darmaga, Bogor 16680 \\ (Diterima 12-12-2010; disetujui 24-03-2011)
}

\begin{abstract}
Quality improvement of ramie leaves silage by the addition of water soluble carbohydrates (WSC) sources as many as $20 \% \mathrm{~W} / \mathrm{W}$ fresh substance (FS) prior to 42 days of ensiling time was conducted in two experiments. First experiment examined three carbohydrate sources (cassava meal, pollard and coarse grinding corn) for their capacities to improve physical (color, odor, texture and spoilage), fermentative ( $\mathrm{pH}$, protein degradation, organic acid profiles), and utilities characteristics of the silages for ruminants (rumen fermentabilities and digestibilities) in vitro. The silages had bright greenish brown of color, lactic acid odor, and firm textures, categorized as highly fermentable and digestible feeds (dry matter digestibility $>72 \%$ ). Compare to other additives, cassava meal produced better silage. However, high butyric acid and protein degradation proportions in the silage were not seem in line to these data. Coarse grinding corn failed to do its function therefore produced poor silage quality. Second experiment was designed to confirm the previous results. Five carbohydrate sources (cassava meal, pollard, fine grinding corn, rice bran, and cassava extract meal) of the same functions were examined. The results confirmed that cassava meal produced very good ramie leave silages (Fleigh number $>80$ ) while the others produced quite good ramie leaves silage qualities (Fleigh number 40-60). All additives used in the second experiment successed to serve their functions in improving ramie leave silage qualities.
\end{abstract}

Key words: additive, ramie, silage, water soluble carbohydrate

\section{PENDAHULUAN}

Upaya integrasi usaha tanaman rami melalui pemanfaatan hasil ikutan daun rami menjadi pakan ternak telah dilaporkan oleh Despal (2007). Produksi hijauan rami di daerah beriklim sedang mencapai 100 ton ha/tahun dengan proporsi dalam bahan kering sebesar 38\% hijauan daun dan $62 \%$ hijauan batang sedangkan di daerah tropis dapat mencapai 3 kali lipat (Angelini et al., 2000). Selain mengandung semua nutrien utama yang diperlukan oleh ternak (Duarte et al., 1997), setara dengan lucerne dan alfalfa (Ferreira et al., 2007), daun rami dapat digolongkan hijauan sumber protein karena mengandung 21\% protein kasar (PK), dan 20\% serat kasar (SK) (Duarte et al., 1997) yang dibutuhkan dalam ransum ternak ruminansia terutama

\footnotetext{
* Korespondensi:

Telp: 0251-8626212.

E-mail: despal04@yahoo.com; despal@ipb.ac.id
}

ternak perah. Penggunaan daun rami 20\% dan 33\% dalam ransum domba berbasis rumput lapang yang disertai suplementasi $\mathrm{Cu}, \mathrm{P}$, dan metionina, mampu mengatasi kehilangan bobot badan domba selama musim kemarau dan meningkatkan kandungan protein ransum mendekati rekomendasi kebutuhan ternak (Despal, 2007).

Daun rami diperoleh dari sisa pemanenan batang yang dilakukan secara periodik dengan interval 6 kali setahun di daerah tropis atau 3 kali setahun di daerah beriklim sedang (Angelini et al., 2000). Agar dapat digunakan sebagai pakan harian ternak ruminansia, maka pengawetan basah menjadi silase daun rami perlu dilakukan.

Silase adalah pakan yang diawetkan melalui proses ensilasi, yaitu proses pengawetan pakan atau hijauan dengan menggunakan kerja spontan fermentasi asam laktat dalam kondisi anaerob. Bakteri asam laktat epifit (BAL) memfermentasi karbohidrat terlarut air dalam tanaman menjadi asam laktat dan sebagian kecil diubah menjadi asam asetat. Karena produksi asam- 
asam tersebut, $\mathrm{pH}$ materi yang diensilasi menurun dan mikrob perusak dihambat pertumbuhannya (Chen \& Weinberg, 2008). Peternak dapat menyediakan hijauan dengan kualitas yang stabil dan tidak banyak bergantung pada cuaca (Cavallarin et al., 2005) dan menghasilkan kandungan nutrisi yang lebih tinggi dibandingkan hay. Teknologi tersebut di Indonesia yang terletak di daerah tropis, mengalami beberapa kendala.

Kandungan air hijauan $(>80 \%)$ dan kapasitas bufer yang tinggi menyebabkan protein mudah mengalami proteolisis (Miron et al., 2006; Hassanat et al., 2007). Karbohidrat terlarut air dan BAL yang rendah serta kadar serat yang tinggi (Elferink et al., 2000) menghasilkan silase berkualitas rendah. Agar mendapatkan silase yang baik, kadar air hijauan perlu diturunkan hingga $60 \%-70 \%$, meningkatkan kandungan karbohidrat terlarut air sehingga BAL dapat tumbuh dengan baik, menghindari pertumbuhan jamur dan mikroba merugikan, menurunkan kehilangan bahan kering (BK), dan protein kasar (PK) selama ensilasi (Nishino et al., 2003). Salah satu upaya meningkatkan kualitas silase hijauan tropis adalah dengan penggunaan aditif pada proses ensilasi yang dapat menstimulasi fermentasi BAL (Nishino \& Touno, 2005; Bureenok et al., 2006; Rizk et al., 2005; Jarkauskas \& Vrotniakiene, 2004; Cavallarin \& Borreani, 2008; Hassanat et al., 2007; Kondo et al., 2004 a ; 2004 ${ }^{\text {b }}$ ) dengan penambahan bahan yang mengandung karbohidrat mudah terlarut dalam jumlah tinggi (Jarkauskas \& Vrotniakiene, 2004; Kozelov et al., 2008) dan penambahan absorban atau penyerap air (Nishino et al., 2007).

Penelitian bertujuan untuk membandingkan penggunaan beberapa sumber karbohidrat (gaplek, pollard, jagung, onggok dan dedak) terlarut air pada proses ensilasi terhadap karakteristik fisik, fermentatif dan utilitas silase daun rami.

\section{MATERI DAN METODE}

\section{Percobaan I}

Penyediaan bahan silase. Percobaan I menguji pengaruh penambahan 3 sumber karbohidrat sebelum ensilasi (gaplek, pollard dan jagung giling) terhadap kualitas silase daun rami yang dihasilkan. Daun rami yang diensilasi diperoleh dari kebun petani anggota Koppontren Darussalam Garut. Sumber karbohidrat yang digunakan diperoleh dari feedmill sekitar Bogor. Percobaan dilakukan pada bulan Juli-Desember 2008.

Pembuatan silase. Sebanyak $2 \mathrm{~kg}$ daun rami segar yang sudah dipotong-potong menjadi $2 \mathrm{~cm}$ dimasukkan secara berselang seling dengan $400 \mathrm{~g}$ sumber karbohidrat ke dalam silo plastik berukuran $28 \times 50 \mathrm{~cm}$ yang sesuai dengan banyaknya material yang diensilasi. Udara dalam kantong dikeluarkan dengan bantuan pompa vakum Pollicon merek Phillips. Kantong yang sudah kedap udara kemudian ditutup dan kantong plastik dilapisi hingga 3 lapisan agar tidak bocor. Kantong tersebut selanjutnya dimasukkan ke dalam polybag 60 x $120 \mathrm{~cm}$ agar tidak ada penetrasi cahaya. Ensilasi berlangsung anaerob pada suhu ruang selama 42 hari.
Analisis sampel. Peubah yang diukur pada percobaan ini adalah a) karakteristik fisik silase meliputi perubahan warna, aroma, tekstur dan keberadaan mikrob pembusuk; b) karakteristik fermentatif silase, yaitu nilai $\mathrm{pH}$, kehilangan $\mathrm{BK}$, perombakan protein, karbohidrat mudah larut air dan profil asam organik yang dihasilkan dari ensilasi; c) utilitas silase daun rami secara in vitro ditentukan berdasarkan fermentabilitas bahan organik membentuk volatile fatty acid (VFA), fermentabilitas protein menghasilkan amonia $\left(\mathrm{NH}_{3}\right)$, kecernaan $\mathrm{BK}$ dan bahan organik (BO).

Pengukuran pH menggunakan prosedur Naumann \& Bassler (1997). Sebanyak $10 \mathrm{~g}$ silase dicampur $100 \mathrm{ml}$ akuades, dihancurkan dengan blender selama 1 menit dengan kecepatan $4.000 \mathrm{rpm}$. Setelah itu, $\mathrm{pH}$ meter yang sudah ditera terhadap larutan standar $(\mathrm{pH} 4$ dan $\mathrm{pH} 7)$, dimasukkan ke dalam sampel dan dilakukan pembacaan $\mathrm{pH}$ setelah 30 detik (stabil).

Kehilangan BK dan PK dihitung dari selisih BK dan PK awal dengan BK dan PK yang terdapat pada silase daun rami. Analisis BK dilakukan menggunakan oven pada suhu $105{ }^{\circ} \mathrm{C}$ hingga beratnya stabil. Analisis konsentrasi PK menggunakan metode Kjehldal (Nauman \& Bassler, 1997). Protein yang dirombak selama ensilasi membentuk senyawa $\mathrm{NH}_{3}$, dihilangkan dari silase dengan memanaskan silase, yang sudah terlebih dahulu ditambahkan $\mathrm{NaOH} 1 \mathrm{M}$ hingga $\mathrm{pH}>10$ pada oven 90 ${ }^{\circ} \mathrm{C}$ selama 6 jam sebagaimana prosedur yang digunakan oleh Carro \& Miller (1999).

Pengukuran asam organik menggunakan metode Bevilacqua \& Califano (1989). Sebanyak 5 g sampel ditimbang dan ditambahkan ke dalam $50 \mathrm{ml}$ bufer $(0.5 \%$ $\mathrm{b} / \mathrm{N}\left(\left(\mathrm{NH}_{4}\right) 2 \mathrm{HPO}_{4}\right.$ pada $\mathrm{pH} 2,24$ dengan $\left.\mathrm{H}_{3} \mathrm{PO}_{4}\right)$ yang dilarutkan pada asetonitril $(0.4 \% \mathrm{v} / \mathrm{N}))$. Campuran yang dihasilkan dihomogenasi dan diekstraksi selama 1 jam, kemudian disentrifugasi pada $7.000 \mathrm{~g}$ sebanyak 6 kali dengan masing-masing sentrifugasi selama 5 menit. Supernatan yang dihasilkan disaring dengan kertas saring membran berukuran 0,45 $\mu \mathrm{m}$ sebanyak dua kali. Supernatan yang sudah disaring diinjeksikan ke HPLC (Jasco LC-900) yang dilengkapi dengan detektor Jasco UV-980, column Marchery Nagel C18 (120 x 5 mm) dengan temperatur $15^{\circ} \mathrm{C}$ di bawah ambien sampai suhu $80^{\circ} \mathrm{C}$. Standar internal yang digunakan adalah reagen HPLC (Sigma Chemical Co., St.Louis, MO). Asam-asam organik muncul ketika supernatan yang telah diinjeksikan ke dalam HPLC dimasukkan ke dalam white cheese pickled berstandar eksternal dari masing-masing asam organik. Sampel tersebut melewati UV detektor dan terbaca oleh chromatograph sebagai rangkaian puncakpuncak asam-asam organik. Puncak asam organik laktat, asetat, dan butirat muncul berturut-turut pada menit ke-7, 8, dan 24.

Kadar VFA dan $\mathrm{NH}_{3}$ silase diukur in vitro. Sebanyak $1 \mathrm{~g}$ silase daun rami yang sudah dikeringkan, digiling dan disaring menggunakan saringan berukuran $0,5 \mathrm{~mm}$. Sampel dimasukkan ke dalam tabung fermentor bervolume $50 \mathrm{ml}$, kemudian ditambahkan $12 \mathrm{ml}$ larutan bufer McDougall dan $8 \mathrm{ml}$ cairan rumen lalu diaduk dengan gas $\mathrm{CO}_{2}$ selama 30 detik dan ditutup rapat dengan prop karet yang berventilasi, kemudian diinkubasi selama 6 jam di dalam shaker water bath bersuhu $39{ }^{\circ} \mathrm{C}$. Setelah 
inkubasi, ditambahkan 2-3 tetes $\mathrm{HgCl}_{2}$ jenuh ke dalam tabung fermentor untuk menghentikan aktivitas mikrob, kemudian tabung fermentor disentrifugasi dengan kecepatan 10.000 rpm selama 10 menit. Supernatan digunakan untuk analisis $\mathrm{NH}_{3}$ dan VFA. Analisis konsentrasi amonia dilakukan dengan metode mikrodifusi Conway, sedangkan produksi VFA diukur dengan teknik destilasi uap/steam destilation (General Laboratory Procedure, 1966).

Kecernaan silase daun rami pada ternak ruminansia diestimasi menggunakan metode Hohenheim gas test seperti yang dijelaskan oleh Menke et al. (1979). Sebanyak $230 \mathrm{mg}$ sampel silase daun rami ditimbang, kemudian dimasukkan ke dalam syringe bervolume 100 $\mathrm{ml}$. Sebanyak $30 \mathrm{ml}$ media yang terdiri atas campuran cairan rumen dan larutan media dengan perbandingan $1: 2$ ditambahkan ke dalam syringe yang sudah berisi sampel. Syringe tersebut ditempatkan pada rotor dan dimasukkan dalam oven bersuhu $39{ }^{\circ} \mathrm{C}$. Fermentasi dihentikan pada jam ke-24 dan produksi gas dibaca. Kecernaan bahan organik (organic matter digestibility= OMD) diestimasi dari produksi gas berdasarkan formula OMD $(\%)=14,88+0,889$ PG + 0,045 PK + 0,065 XA dengan $\mathrm{PG}=$ produksi gas $(\mathrm{ml} / 200 \mathrm{mg} \mathrm{BK}), \mathrm{XA}=$ kadar abu (g/kg BK) dan $\mathrm{PK}=$ protein kasar $(\mathrm{g} / \mathrm{kg} \mathrm{BK})$.

Rancangan percobaan dan analisis statistik. Percobaan ini menggunakan rancangan acak lengkap (RAL) dengan 3 ulangan. Karakteristik fisik dan profil asam organik digambarkan secara deskriptif, sedangkan pengujian utilitas menggunakan rancangan acak kelompok (RAK) dengan waktu pengambilan cairan rumen yang berbeda sebagai kelompok seperti yang digunakan oleh Arroquy et al. (2005), Tessema \& Baars (2004), Tafaj et al. (2005), dan Ben-Ghedalia et al. (2001). Perbedaan nilai tengah antar perlakuan dianalisa dengan sidik ragam (ANOVA) diikuti dengan uji Duncan.

\section{Percobaan II}

Percobaan II merupakan konfirmasi terhadap hasil pengukuran percobaan I yang kontradiktif.

Penyediaan bahan silase. Sebanyak 5 sumber karbohidrat ditambahkan sebelum ensilasi (gaplek, pollard, jagung giling halus, dedak dan onggok). Daun rami yang diensilasi diperoleh dari kebun petani anggota Koppontren Darussalam Garut, sedangkan karbohidrat yang digunakan diperoleh dari feedmill sekitar Bogor. Percobaan dilakukan pada bulan Maret-Juli 2009.

Pembuatan silase dan analisis sampel. Prosedur pembuatan silase sama dengan percobaan I. Peubah yang diamati adalah karakteristik fisik (warna, aroma, tekstur, dan tingkat kerusakan) dan karakteristik fermentatif silase ( $\mathrm{pH}$, kehilangan $\mathrm{BK}$, perombakan protein, karbohidrat terlarut air, nilai Fleigh). Perombakan protein selama ensilasi menjadi $\mathrm{NH}_{3}$ diukur dengan teknik difusi Conway (General Laboratory Procedure, 1966). Nilai Fleigh dihitung berdasarkan rumus NF= $220+(2 \times$ BK $(\%)-15)-(40 \times \mathrm{pH})$ dengan $\mathrm{NF}=$ Nilai Fleigh; BK= Bahan Kering. Nilai NF 85-100 menyatakan silase berkualitas baik sekali, 60-80 silase berkualitas baik, 40-60 silase berkualitas cukup baik, 20-40 silase berkualitas sedang dan silase berkualitas kurang baik jika mempunyai NF $<20$ (Indikut et al., 2009).

Rancangan percobaan dan analisis statistik. Percobaan ini menggunakan rancangan acak lengkap (RAL) dengan 3 ulangan. Karakteristik fisik digambarkan secara deskriptif. Perbedaan nilai tengah perlakuan dianalisis dengan ANOVA dilanjutkan dengan uji Duncan.

\section{HASIL DAN PEMBAHASAN}

\section{Percobaan I}

Daun rami yang digunakan dalam pembuatan silase mengandung air $82 \%$ (Tabel 1). Kadar air yang tinggi menyebabkan proporsi BK rendah (18\%) dan kapasitas bufer $(\mathrm{Kb})$ tinggi. Ensilasi hijauan dengan $\mathrm{BK}$ rendah tidak akan menghasilkan fermentasi yang baik dan menyebabkan kehilangan nutrien tinggi (Miron et al., 2006), sedangkan kapasitas bufer tinggi akan menyebabkan tingginya proteolisis protein (Hassanat et al., 2007). Bahan kering yang rendah dan kapasitas bufer yang tinggi akan menyebabkan koefisien fermentasi, yang menggambarkan kualitas silase, menjadi rendah (Weissbach \& Honig, 1996). Kadar BK kurang dari 20\% menyebabkan resiko pembusukan dan kehilangan BK selama ensilasi menjadi tinggi. Bahan basah atau BK rendah seperti daun rami perlu dicampur pakan kering (Nishino et al., 2003) seperti gaplek, pollard, dan jagung yang memiliki BK >87\% (Tabel 1).

Penambahan sumber karbohidrat dengan bahan kering tinggi, seperti gaplek $(87,34 \%)$, pollard $(89,66 \%)$ dan jagung $(88,77 \%)$ sebanyak $20 \%$ B/B bahan segar menghasilkan BK bahan silase daun rami berturut-turut 29,56\%; 29,94\%; dan 29,98\%. Target BK bahan silase dengan penambahan sumber karbohidrat adalah $32 \%$ sesuai dengan rekomendasi Cavallarin et al. (2005) sehingga fermentasi asam butirat dan perombakan protein dapat ditekan. Lebih rendahnya kadar BK dalam bahan silase (30\%) dibandingkan sasaran (32\%) disebabkan oleh rendahnya BK daun rami (18\%) dibandingkan asumsi (20\%) yang digunakan dalam perhitungan.

Ketiga sumber karbohidrat yang digunakan memiliki kadar bahan kering yang hampir sama untuk

Tabel 1. Komposisi nutrien daun rami dan sumber karbohidrat penelitian

\begin{tabular}{lccccc}
\hline \multirow{2}{*}{ Bahan } & \multicolumn{5}{c}{ Komponen } \\
\cline { 2 - 6 } & $\begin{array}{c}\text { BK } \\
(\%)\end{array}$ & $\begin{array}{c}\mathrm{Abu} \\
(\% \mathrm{BK})\end{array}$ & $\begin{array}{c}\text { PK } \\
(\% \mathrm{BK})\end{array}$ & $\begin{array}{c}\text { LK } \\
(\% \mathrm{BK})\end{array}$ & $\begin{array}{c}\text { SK } \\
(\% \mathrm{BK})\end{array}$ \\
\hline Daun rami & 18,00 & 20,50 & 16,35 & 6,36 & 13,61 \\
Gaplek & 87,34 & 2,37 & 3,34 & 1,16 & 5,50 \\
Pollard & 89,66 & 3,49 & 15,15 & 5,18 & 7,08 \\
Jagung & 88,77 & 0,81 & 7,49 & 5,11 & 2,31 \\
\hline
\end{tabular}

Keterangan: $\mathrm{BK}=$ bahan kering; $\mathrm{PK}=$ protein kasar; $\mathrm{LK}=$ lemak kasar; $\mathrm{SK}=$ serat kasar 
menyerap kelebihan air dari daun rami. Kemampuan daya serap karbohidrat ditentukan oleh luas permukaan serap atau ukuran partikelnya, dan keberadaan coating, seperti serat dan lemak, yang dapat menurunkan daya serap air bahan. Kadar protein yang tinggi pada pollard $(15,15 \%)$ akan berkontribusi lebih tinggi terhadap PK bahan silase, namun kadar SK (7,08\%) dan lemak (5,18\%) yang juga tinggi, dapat menurunkan daya serapnya dibandingkan dengan gaplek yang mengandung lemak hanya 1,16\% dan SK 5,50\%.

Karakteristik fisik silase daun rami. Kualitas silase dapat dilihat dari karakteristik fisik (Ferreira \& Mertens, 2005) setelah silase dibuka, meliputi warna, bau, tekstur dan adanya mikrob pembusuk (Haustein, 2003). Secara umum silase daun rami yang dihasilkan pada percobaan ini berwarna hijau kecoklatan. Proporsi warna coklat yang lebih banyak pada silase yang ditambah pollard menyebabkan warnanya lebih gelap dibandingkan yang ditambah gaplek dan jagung. Semakin gelap silase yang dihasilkan, maka kualitas silase semakin rendah.

Silase daun rami ditambah gaplek lebih masam dibandingkan dengan perlakuan silase lainnya, memiliki tekstur utuh, halus dan kering, sedangkan yang ditambah jagung tidak utuh, lembab, berlendir karena adanya mikrob pembusuk. Bagian silase yang mengalami pembusukan tersebut mencapai 8,4\%. Hal ini diduga karena ukuran partikel jagung yang digunakan kurang halus sehingga menyebabkan luas permukaan serap dari jagung berkurang dan karbohidratnya lebih sulit dimanfaatkan oleh bakteri asam laktat. Keuntungan lain ukuran partikel yang lebih halus juga mencegah kebocoran silo selama ensilasi sehingga fermentasi anaerob dapat berlangsung sempurna (DePeters et al., 2003). Karakteristik fisik silase daun rami beraditif gaplek dan pollard mendekati kriteria silase berkualitas baik yakni berwarna hijau kecoklatan, beraroma asam, bertekstur utuh, dan halus (Haustein, 2003) serta tidak terdapat mikrob pembusuk.

Karakteristik fermentatif silase. Silase daun rami yang diberi gaplek memiliki nilai $\mathrm{pH}$ yang lebih rendah dibandingkan yang diberi pollard dan jagung (Tabel 2). Hal ini disebabkan oleh tingginya porsi karbohidrat terlarut $(5 \%)$ dan rendahnya protein $(3,34 \%)$ pada gaplek. Kadar karbohidrat terlarut air yang tinggi menyediakan karbohidrat terlarut yang diperlukan oleh BAL untuk tumbuh. Fermentasi substrat tersebut menghasilkan asam organik yang menyebabkan $\mathrm{pH}$ turun, sedangkan kadar protein yang rendah menyebabkan kapasitas bufer rendah sehingga pengasaman lebih mudah terjadi. Meskipun pollard mengandung karbohidrat terlarut air yang lebih tinggi $(12,5 \%)$ yang mampu menyediakan lebih banyak karbohidrat terlarut bagi BAL, namun karena kadar proteinnya yang tinggi $(15,5 \%)$ menyebabkan kapasitas bufer yang tinggi pula.

Haustein (2003) mengklasifikasikan bahwa silase yang baik memiliki $\mathrm{pH}<4,2$ dan berkualitas sedang jika memiliki pH berkisar 4,5-5,2. Berdasarkan kriteria Haustein (2003), maka silase daun rami yang diberi gaplek dapat dikelompokkan pada silase berkualitas baik, sedangkan silase daun rami yang diberi pollard berkualitas sedang. Jagung yang digunakan pada percobaan ini menghasilkan silase daun rami berkualitas rendah.

Proporsi protein yang didegradasi menjadi amonia selama proses ensilasi berkisar $20 \%-31 \%$ dan tidak dipengaruhi oleh jenis aditif. Silase dikategorikan berkualitas baik jika kadar amonia $<50 \mathrm{~g} / \mathrm{kg}$ total $\mathrm{N}$ atau setara dengan degradasi protein $<4,1 \%$ (Zamudio et al., 2009). Tingginya perombakan protein dapat disebabkan oleh tingginya kadar protein daun rami (>16\%) dan kadar air yang mengarah pada fermentasi asam butirat (Cavallarin et al., 2005).

Fermentasi silase yang baik didominasi oleh kerja BAL dan menghasilkan konsentrasi asam organik yang didominasi oleh asam laktat (Chen \& Weinberg, 2008). Semakin tinggi konsentrasi asam laktat, maka semakin tinggi kualitas silase yang dihasilkan. Sebaliknya, proses fermentasi silase yang kurang baik menyebabkan Clostridia berkembang yang dicirikan oleh tingginya kadar asam butirat (Elferink et al., 2000).

Penambahan karbohidrat terlarut air yang ditujukan untuk meningkatkan preservasi silase, dengan meyakinkan bahwa bakteri asam laktat mendominasi fase fermentasi tidak dapat diperlihatkan dari profil asam organik pada percobaan ini. Secara keseluruhan asam organik yang dihasilkan sangat rendah. Arvidsson et al. (2009) memperlihatkan silase berkualitas baik dengan kadar asal laktat sebesar 50,68-95,03 g/kg BK dan proporsi asam laktat, asetat, propionat dan butirat berturut-turut terhadap jumlah keempat asam organik tersebut berkisar 75,9\%-92,8\%; 5,9\%-21,0\%; 0,7\%-6,3\%; dan $0,32 \%-1,27 \%$. Asam laktat yang dihasilkan pada percobaan ini berkisar 0,091-0,125 $\mathrm{g} / \mathrm{kg}$ BK dengan proporsi asam laktat, asetat dan butirat terhadap total asam organik berturut-turut berkisar 52,18\%-79,26\%; $1,28 \%-2,81 \%$; dan $10,89 \%-23,64 \%$.

Tabel 2. Karakteristik fermentatif silase daun rami beraditif

\begin{tabular}{lccc}
\hline \multirow{2}{*}{ Parameter } & \multicolumn{3}{c}{ Aditif } \\
\cline { 2 - 4 } & Gaplek & Pollard & Jagung \\
\hline $\mathrm{pH}$ & $3,15 \pm 0,16^{\mathrm{a}}$ & $4,47 \pm 0,14^{\mathrm{b}}$ & $6,16 \pm 0,12^{\mathrm{c}}$ \\
$\begin{array}{l}\text { Degradasi protein (\%) } \\
\begin{array}{l}\text { Total asam organik } \\
(\mathrm{g} / \mathrm{kg} \text { BK) }\end{array}\end{array}$ & $0,1745,6$ & $20,5 \pm 4,3$ & $23,8 \pm 7,8$ \\
$\begin{array}{l}\text { Asam laktat } \\
\text { (g/kg BK) }\end{array}$ & 0,091 & 0,119 & 0,158 \\
$\begin{array}{l}\text { Asam asetat } \\
(\mathrm{g} / \mathrm{kg} \text { BK) }\end{array}$ & 0,005 & 0,002 & 0,125 \\
$\begin{array}{l}\text { Asam butirat } \\
(\mathrm{g} / \mathrm{kg} \text { BK) }\end{array}$ & 0,041 & 0,026 & 0,017 \\
$\begin{array}{l}\text { Asam laktat (\% total } \\
\text { asam organik) }\end{array}$ & 52,18 & 64,08 & 79,26 \\
$\begin{array}{l}\text { Asam asetat }(\% \text { total } \\
\text { asam organik) }\end{array}$ & 2,81 & 1,28 & 1,29 \\
$\begin{array}{l}\text { Asam butirat (\% total } \\
\text { asam organik) }\end{array}$ & 23,64 & 13,88 & 10,89 \\
\hline
\end{tabular}

Keterangan: Superskrip berbeda pada baris yang sama menunjukkan berbeda nyata $(\mathrm{P} \varangle, 05)$. 
Selain total asam organik yang rendah, proporsinya juga tidak sejalan dengan karakter fisik dan $\mathrm{pH}$ silase. Silase daun rami yang diberi gaplek dan pollard yang memiliki nilai $\mathrm{pH}$ rendah dan berkarakter fisik baik, memiliki proporsi asam butirat yang lebih tinggi dibandingkan silase daun rami yang diberi jagung. Kontradiksi hasil yang ditemukan tersebut dapat disebabkan oleh sulitnya kuantifikasi asam organik seperti yang dikemukakan oleh Hiraoka et al. (2010). Meskipun menggunakan HPLC, pemisahan dan kuantifikasi asam organik membutuhkan sistem preparasi yang ekstensif termasuk ekstraksi fase padat, ekstraksi fase cair-cair, dan derivatisasi.

Utilitas silase daun rami untuk ruminansia. Fermentabilitas bahan organik silase dalam rumen menghasilkan volatile fatty acid (VFA) yang digunakan sebagai sumber energi utama untuk mikroba rumen (Orskov \& Ryle, 1990). Silase daun rami yang diberi pollard menghasilkan VFA lebih tinggi dibandingkan yang diberi gaplek dan jagung (Tabel 3). Meskipun gaplek lebih mudah difermentasi dibandingkan pollard, namun karena sebagian besar bahan yang mudah larut dari gaplek sudah difermentasi oleh BAL pada ensilasi, maka bagian yang tersisa pada fermentasi mikroba rumen menjadi lebih rendah. Fermentabilitas silase yang diberi jagung lebih rendah. Hal tersebut dapat disebabkan partikel jagung yang kurang halus, sehingga lebih sulit difermentasi dalam rumen. Namun demikian, semua silase yang dihasilkan masih tergolong pada pakan yang mudah difermentasi dalam rumen dengan kisaran VFA yang lebih tinggi dibandingkan kisaran VFA pakan pada penelitian Wang et al. (2009), yaitu sebesar 93,4-99,6 mM.

Amonia adalah sumber nitrogen penting untuk sintesis protein mikrob dalam rumen (Despal, 2005). Namun demikian kadar amonia rumen yang terlalu tinggi tidak dapat dimanfaatkan jika tidak diimbangi dengan ketersediaan kerangka karbon dan hal tersebut menggambarkan degradasi protein pakan yang tinggi. Kadar $\mathrm{NH}_{3}$ pada silase yang diberi pollard lebih tinggi dibandingkan dengan yang diberi gaplek dan jagung. Rendahnya kadar amonia pada silase yang diberi gaplek dan jagung disebabkan oleh kandungan protein gaplek $(3,34 \%)$ dan jagung $(7,49 \%)$ yang lebih rendah, dibandingkan pollard $(15,15 \%)$. Rataan $\mathrm{NH}_{3}$ silase berkisar 13-19 mM, berada pada kisaran optimum untuk sintesis protein mikrob di rumen (McDonald et al. 2002), namun lebih tinggi dibandingkan kisaran kecukupan menurut

Tabel 3. Utilitas silase daun rami dengan sumber karbohidrat berbeda untuk ruminansia (in vitro)

\begin{tabular}{lccc}
\hline \multirow{2}{*}{ Parameter } & \multicolumn{3}{c}{ Aditif } \\
\cline { 2 - 4 } & Gaplek & Pollard & Jagung \\
\hline VFA $(\mathrm{mM})$ & $127,7 \pm 4,9^{\mathrm{a}}$ & $164,2 \pm 11,7^{\mathrm{b}}$ & $135,0 \pm 12,1^{\mathrm{a}}$ \\
$\mathrm{NH}_{3}(\mathrm{mM})$ & $13,2 \pm 2,1^{\mathrm{a}}$ & $19,4 \pm 2,9^{\mathrm{b}}$ & $11,2 \pm 0,4^{\mathrm{a}}$ \\
\hline
\end{tabular}

Keterangan: Superskrip berbeda pada baris yang sama menunjukkan berbeda nyata $(\mathrm{P}<0,05)$. VFA= volatile fatty acid; $\mathrm{NH}_{3}=$ amonia
Wannapat et al. (2009), yaitu 5,4-8,8 mM.

Kecernaan bahan organik (KCBO) silase daun rami yang diberi sumber karbohidrat sejalan dengan produksi gas (Gambar 1). Kecernaan silase daun rami yang diberi karbohidrat memperlihatkan pola yang sama dengan fermentabilitas rumen. Meskipun silase yang diberi jagung lebih tahan degradasi dalam rumen dibandingkan dengan silase yang diberi pollard, namun menghasilkan kecernaan bahan organik yang paling tinggi $(73,6 \%)$. Silase beraditif yang dihasilkan dalam penelitian ini tergolongkan pakan berkecernaan tinggi, lebih tinggi dibandingkan dengan silase hijauan sorgum yang berkisar hanya 50\%-54\% (Marco et al., 2009)

\section{Percobaan II}

Bahan kering daun rami yang digunakan pada percobaan ini lebih rendah dibandingkan pada percobaan I (Tabel 4). Hal ini disebabkan daun rami yang digunakan pada percobaan II dipanen pada musim hujan. Kandungan PK daun rami memperlihatkan nilai yang relatif sama dengan yang diperoleh pada percobaan I.

Kandungan karbohidrat terlarut air daun rami $(3,08 \%)$ tergolong sangat rendah sama seperti kebanyakan hijauan tropis (Downing et al., 2008). Kandungan

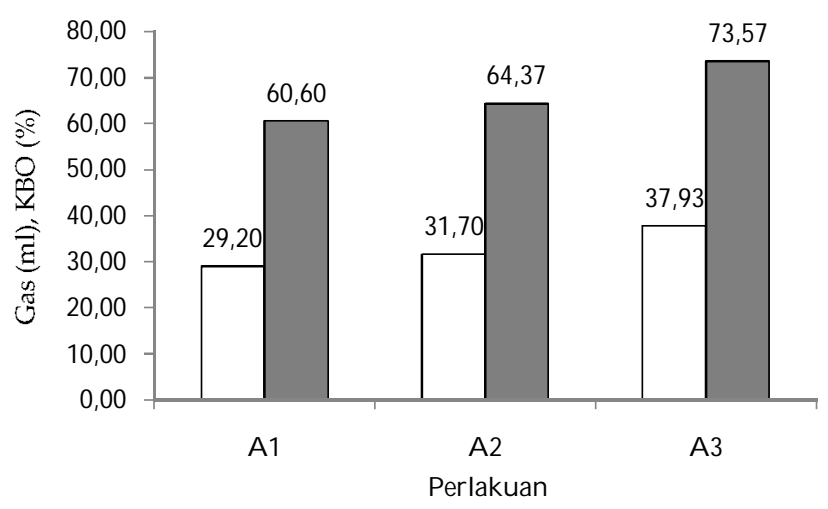

Gambar 1. Produksi gas ( $\square)$ dan kecernaan bahan organik $(\mathrm{KBO}=\mathbf{\square})$ silase daun rami beraditif. $\mathrm{A} 1=$ silase beraditif gaplek; $\mathrm{A} 2=$ silase beraditif pollard; $\mathrm{A} 3=$ silase beraditif jagung.

Tabel 4. Kandungan nutrien daun rami dan sumber karbohidrat

\begin{tabular}{lcrrc}
\hline Bahan & $\begin{array}{c}\text { BK } \\
(\%)\end{array}$ & $\begin{array}{c}\text { Abu } \\
(\% \mathrm{BK})\end{array}$ & $\begin{array}{c}\text { PK } \\
(\% \mathrm{BK})\end{array}$ & $\begin{array}{c}\text { Karbohidrat } \\
\text { terlarut air } \\
(\% \mathrm{BK})\end{array}$ \\
\hline Daun rami & 11,14 & 17,37 & 16,7 & 3,08 \\
Onggok & 82,85 & 19,18 & 2,02 & 3,10 \\
Jagung & 86,48 & 1,68 & 10,88 & 3,40 \\
Pollard & 86,26 & 5,16 & 15,53 & 12,52 \\
Gaplek & 82,28 & 5,92 & 1,52 & 5,04 \\
Dedak & 85,68 & 11,59 & 11,21 & 5,42 \\
\hline
\end{tabular}

Keterangan: $\mathrm{BK}=$ bahan kering; $\mathrm{PK}=$ protein kasar. 
karbohidrat terlarut air yang rendah menghasilkan koefisien fermentatif yang rendah (Weissbach \& Honig, 1996). Kadar karbohidrat terlarut air tanaman bervariasi dan dipengaruhi oleh jenis dan varietas tanaman (Miron et al., 2007), umur tanaman (Miron et al., 2006; Nadeau, 2007) dan pola tanam (Dawo et al., 2007). Menurut McDonald et al. (1991), kandungan karbohidrat terlarut air dalam hijauan untuk pembuatan silase yang berkualitas baik berkisar 3-5\%. Sumber karbohidrat yang digunakan pada percobaan ini memiliki kandungan karbohidrat terlarut air yang lebih tinggi dibandingkan dengan daun rami, yang diharapkan mampu menyediakan karbohidrat terlarut air untuk meningkatkan kinerja BAL.

Karakteristik fisik silase. Silase rami yang diberi pollard, gaplek dan dedak yang dihasilkan berwarna hijau kecoklatan dan lebih terang dibandingkan dengan yang diberi onggok dan jagung. Aroma silase daun rami yang diberi gaplek lebih asam dibandingkan dengan silase lainnya. Secara keseluruhan tekstur silase yang dihasilkan utuh, tidak berlendir, dan tidak menggumpal. Silase yang diberi gaplek menunjukkan adanya bercak jamur berwarna putih, sedangkan pada silase yang diberi dedak ditemukan bercak jamur berwarna putih dan merah. Namun jumlah silase yang terkontaminasi atau ditumbuhi jamur tersebut sangat sedikit $(\varangle 0,1 \%)$. Jamur yang terdapat pada silase yang diberi gaplek dan dedak mungkin disebabkan adanya udara pada silo. Spesies atau genera Jamur (kapang dan khamir) yang diidentifikasi pada bale-silage oleh O'Brian et al. (2007) diantaranya Penicillium roqueforti, Schizophyllum commune, Mucoraceous mould, Penicillium paneum, Fusarium culmorum, Fusarium avenaceum, Trichoderma, Pichia fermentans, Geotrichum, Pichia anomala, dan Candida boidinii.

Karakteristik fermentatif silase. Bahan kering silase daun rami yang dihasilkan sangat rendah dibandingkan BK silase yang diharapkan berkisar 30\% yang dihitung secara teoritis dengan asumsi bahwa BK asal bahan berkisar 16\%. Namun karena BK daun rami yang digunakan hanya berkisar $11 \%$ dan terjadi perombakan bahan kering selama proses ensilasi, maka BK yang dihasilkan kurang dari 22\%. Kadar BK silase yang diberi dedak, pollard dan gaplek lebih tinggi dibandingkan dengan yang diberi jagung dan onggok. Tingginya BK pada ketiga silase tersebut disebabkan oleh degradasi BK yang lebih rendah (Tabel 5).

Kehilangan BK selama ensilasi dipengaruhi oleh kandungan nutrien bahan dan mikroorganisme yang terlibat pada ensilasi (McDonald et al., 1991). BK yang hilang selama proses fermentasi diubah menjadi N-amonia, asam organik, gas seperti karbodioksida dan panas (Borreani et al., 2007). BK yang hilang pada percobaan ini masih dalam batas normal, yaitu berkisar 2,3\%-6,1\%. Kehilangan BK silase sebanyak $2 \%-8 \%$ juga ditemukan oleh Cavallarin et al. (2005) pada ensilasi hijauan sainfoin (Onobrychis viciifolia Scop).

Silase daun rami yang diberi gaplek memiliki nilai $\mathrm{pH}$ lebih rendah dibandingkan yang lainnya kecuali dengan yang diberi pollard. Seperti pada percobaan ke1, penambahan gaplek mampu menurunkan $\mathrm{pH}$ lebih cepat dibandingkan dengan penambahan aditif lainnya. Penurunan $\mathrm{pH}$ yang cepat menghambat kerja mikroba pembusuk sehingga degradasi nutrien dapat ditekan (Chen \& Weinberg, 2008). Nilai pH silase yang diberi gaplek berada pada kisaran optimal menurut Haustein (2003), yaitu $\mathrm{pH}<4,2$, sedangkan silase yang beraditif selain gaplek tergolong pada silase berkualitas sedang dengan $\mathrm{pH}$ berkisar 4,5-5,2.

Konsentrasi $\mathrm{NH}_{3}$ silase pada penelitian ini $<1,5 \%$ lebih rendah dibandingkan dengan pada percobaan ke1. Jika dibandingkan dengan total $\mathrm{N}$ pada bahan awal (daun rami + sumber karbohidrat) maka perombakan protein menghasilkan amonia pada silase yang diberi gaplek $(12,68 \%)$ dan onggok $(13,95 \%)$ masih tergolong tinggi menurut klasifikasi Zamudio et al. (2009). Klasifikasi tersebut memberikan batasan total amonia maksimum 5\%. Silase yang dihasilkan masih dalam kisaran kriteria silase berkualitas baik menurut (Elferink et al., 2000) yang hanya mampu mempertahankan nutrien $80 \%-92 \%$ dalam silase jagung. Kehilangan nutrien selama ensilasi tidak hanya ditentukan oleh pertumbuhan mikrob pembusuk, dan kecepatan penurunan $\mathrm{pH}$, namun juga ditentukan oleh sifat dari bahan pakan itu sendiri. Bahan seperti jagung lebih tahan degradasi dibandingkan dengan gaplek atau onggok sehingga menyebabkan kehilangan sedang pada proses ensilasi (Miron et al., 2007).

Tabel 5. Karakteristik fermentatif silase daun rami yang diberi sumber karbohidrat berbeda

\begin{tabular}{|c|c|c|c|c|c|}
\hline \multirow{2}{*}{ Parameter } & \multicolumn{5}{|c|}{ Aditif } \\
\hline & Gaplek & Pollard & Jagung & Dedak & Onggok \\
\hline BK silase $(\%)$ & $20,40 \pm 1,20^{\mathrm{bc}}$ & $20,40 \pm 1,32^{\mathrm{bc}}$ & $19,63 \pm 0,60^{\mathrm{b}}$ & $21,92 \pm 1,08^{c}$ & $17,65 \pm 0,21^{\text {a }}$ \\
\hline $\mathrm{pH}$ & $4,06 \pm 0,02^{\mathrm{a}}$ & $4,51 \pm 0,12^{\mathrm{ab}}$ & $4,78 \pm 0,03^{\mathrm{b}}$ & $4,95 \pm 0,54^{\mathrm{b}}$ & $4,74 \pm 0,05^{\mathrm{b}}$ \\
\hline Amonia silase (\%BK) & $1,26 \pm 0,23^{\mathrm{bc}}$ & $0,92 \pm 0,21^{\mathrm{a}}$ & $1,00 \pm 0,01^{\mathrm{ab}}$ & $0,80 \pm 0,17^{\mathrm{a}}$ & $1,45 \pm 0,23^{c}$ \\
\hline Degradasi BK (\%) & $3,27 \pm 1,20^{\mathrm{ab}}$ & $3,93 \pm 1,32^{\mathrm{ab}}$ & $4,73 \pm 0,60^{\mathrm{bc}}$ & $2,31 \pm 1,08^{\mathrm{a}}$ & $6,11 \pm 0,21^{\mathrm{c}}$ \\
\hline Degradasi protein (\%) & $15,42 \pm 2,49^{b}$ & $5,20 \pm 0,56^{\mathrm{a}}$ & $6,86 \pm 0,49^{a}$ & $5,48 \pm 1,13^{\mathrm{a}}$ & $16,96 \pm 2,74^{\mathrm{b}}$ \\
\hline Karbohidrat terlarut air (\%BK) & $5,99 \pm 0,82^{c}$ & $4,32 \pm 1,43^{\mathrm{bc}}$ & $3,43 \pm 0,96^{\mathrm{ab}}$ & $2,04 \pm 1,17^{\mathrm{a}}$ & $2,99 \pm 1,03^{\mathrm{ab}}$ \\
\hline Nilai Fleigh & $83,26 \pm 1,83^{b}$ & $65,40 \pm 7,29^{\mathrm{ab}}$ & $52,92 \pm 22,14^{\mathrm{a}}$ & $50,84 \pm 1,94^{\mathrm{a}}$ & $50,70 \pm 1,94^{\mathrm{a}}$ \\
\hline
\end{tabular}

Keterangan: Superskrip berbeda pada baris yang sama menunjukkan berbeda nyata $(\mathrm{P}<0,05)$. 
Kecuali pada silase yang diberi gaplek, terdapat kandungan karbohidrat terlarut air silase yang lebih rendah dibandingkan dengan kadar karbohidrat terlarut air pada bahan awal. Penurunan kadar karbohidrat terlarut air pada silase dapat dipahami karena digunakan oleh BAL selama ensilasi untuk memproduksi asam dan menurunkan pH silase (Chen \& Weinberg, 2008; Ennahar et al., 2003). Namun peningkatan karbohidrat terlarut air seperti pada silase yang diberi gaplek tidak banyak ditemukan. Hal tersebut dapat disebabkan oleh jumlah karbohidrat terlarut air yang digunakan oleh BAL lebih rendah dibandingkan dengan pelarutan karbohidrat terikat akibat kerja mikrob dan asam yang dihasilkan. Penurunan $\mathrm{pH}$ yang cepat pada silase yang diberi gaplek dengan perombakan karbohidrat terlarut air rendah, dapat disebabkan oleh rendahnya kapasitas bufer dari silase yang diberi gaplek dibandingkan dengan yang diberi pollard. Tingginya kapasitas bufer pada silase yang diberi pollard dapat disebabkan oleh tingginya kadar serat kasar dan protein pada silase tersebut yang berasal dari pollard.

Nilai Fleigh merupakan indeks karakteristik fermentasi silase berdasarkan nilai $\mathrm{BK}$ dan $\mathrm{pH}$ dari silase (Indikut et al., 2009). Berdasarkan kriteria tersebut, Nilai Fleigh silase daun rami yang diberi gaplek dikategorikan baik sekali, silase yang diberi pollard tergolong berkualitas baik, sedangkan yang lainnya berkualitas cukup baik (Tabel 5).

\section{KESIMPULAN}

Penggunaan gaplek pada proses ensilase daun rami menghasilkan silase yang tergolong berkualitas baik sekali, sedangkan penggunaan pollard, jagung, dedak dan onggok menghasilkan silase daun rami berkualitas cukup baik.

\section{UCAPAN TERIMA KASIH}

Ucapan terimakasih disampaikan kepada DP2M Dikti Kemendiknas atas kepercayaannya untuk mengelola dana penelitian melalui proyek Hibah Bersaing Perguruan Tinggi tahun 2008-2010 yang didesentralisasikan kepada IPB. Kami juga mengucapkan terima kasih kepada petani rami dan pengelola Koppontren Darussalam Garut atas kesediaannya menyediakan materi penelitian dan diskusi-diskusi yang sangat membantu.

\section{DAFTAR PUSTAKA}

Angelini, L. G., A. Lazzeri, G. Levita, D. Fontanelli, \& C. Bozzi. 2000. Ramie (Boehmeria nivea (L.) Gaud.) and Spanish Broom (Spartium junceum L.) fibres for composite materials: agronomical aspects, morphology and mechanical properties. Industrial Crops and Products 11: 145 -161 .

Arroquy, J. I., R. C. Cochran, T. G. Nagaraja, E. C. Titgemeyer, \& D. E. Johnson. 2005. Effect of types of non-fiber carbohydrate on in vitro forage fiber digestion of low-quality grass hay. Anim. Feed Sci. Technol. 120: 93-106.

Arvidsson, K., A. M. Gustavsson, \& K. Martinsson. 2009. Effects of conservation method on fatty acid composition of silage. Anim. Feed Sci. Technol. 148: 241-252.

Ben-Ghedalia, D., R. Solomon, J. Miron, E. Yosef, Z. Zomberg, E. Zukerman, A. Greenberg, \& T. Kipnis. 2001. Effect of water salinity on the composition and in vitro digestibility of winter-annual ryegrass grown in the Arava desert. Anim. Feed Sci. Technol. 91: 139 - 147.

Bevilacqua, A. E. \& A. N. Califano. 1989. Determination of organic acids in dairy products by high-performance liquid chromatography. J. Food Sci. 54 : 1076-1079.

Borreani, G., E. Tabacco, \& L. Cavallarin. 2007. A New Oxygen Barrier Film Reduces Aerobic Deterioration in Farm-Scale Corn Silage. American Dairy Science Association, 2007. [11 Januari 2010]

Bureenok, S., T. Namihira, S. Mizumachi, Y. Kawamoto, \& T. Nakada. 2006. The effect of epiphytic lactic acid bacteria with or without different byproduct from defatted rice bran and green tea waste on napiergrass (Pennisetum purpureum Shumach) silage fermentation. J.Sci.Food Agric. 86: $1073-1077$.

Carro, M. D. \& E. L. Miller. 1999. Effect of supplementing a fibre basal diet with different nitrogen forms on ruminal fermentation and microbial growth in an in vitro semicontinuous culture system (RUSITEC). British J. Nutr. 82, $149-157$.

Cavallarin, L. \& G. Borreani. 2008. Effect of the stage of growth, wilting and inovulation in field pea (Pisum sativum L.) silages, III. Changes in the herbage and silage protein profiles. J. Sci. Food Agric. 88: 237 - 237.

Cavallarin, L., S. Antoniazzi., G. Borreani, \& E. Tobacco. 2005. Effects of wilting and mechanical conditioning on proteolysis in sainfoin (Onobrychis viciifolia Scrop) wilted herbage and silage. J. Sci. Food Agric. 85: 831-838.

Chen, Y. \& Z. G. Weinberg. 2008. Changes during aerobic exposure of wheat silages. Anim. Feed Sci. Technol.154: $76-82$.

Dawo, M. I., J. M. Wilkinson, F. E. T. Sanders, \& D. J. Pilbeam. 2007. The yield and quality of fresh and ensiled plant material from intercropped maize (Zea mays) and beans (Phaseolus vulgaris). J. Sci. Food Agric. 87: 1391-1399.

DePeters, E. J., G. Getachew, J. G. Fadel, R. A. Zinn, S. J. Taylor, J. W. Pareas, R. G. Hinders, \& M. S. Aseltine. 2003. In vitro gas production as a method to compare fermentation characteristics of steam-flaked corn. Anim. Feed Sci. Technol. 105:109-122.

Despal. 2005. Nutritional Properties of Urea Treated Cocoa Pod for Ruminant. Cuvillier Verlag, Goettingen.

Despal. 2007. Suplementasi nutrien defisien untuk meningkatkan penggunaan daun rami (Boehmeria nivea, L. Gaud) dalam ransum domba. Med Pet. 30 (3): 181-188.

Downing, T. W., A. Buyserie., M. Gamroth, \& P. French. 2008. Effect of Water Soluble Carbohydrates on Fermentation Charateristics of Ensiled Perennial Ryegrass. The Profesional Animal Scientist 24:35-39

Duarte, A. A, V. C. Sgarbieri, \& E. R. B. Juniar. 1997. Composition and nutritive value of ramie leaf flour for monogastric animals. Reviata PAB : 32 (12).

Elferink, S. J. W. H. O., F. Driehuis, J. C. Gottschal, \& S. F. Spoelstra. 2000. Silage fermentation processes and their manipulation. In: Mannetje, L.T. Silage making in the tropics with particular emphasis on smallholders. Proceedings of the FAO electronic conference on tropical silage 1 September to 15 December 1999.

Ennahar. S., Y. Cai. \& Y. Fujita. 2003. Phylogenetic diversity of lactic acid bacteria associated with paddy rice silage as determined by $16 \mathrm{~S}$ ribosomal DNA analysis. Applied and Environmental Microbiology 69: 444-451.

Ferreira, G. \& D. R. Mertens. 2005. Chemical and physical characteristics of corn silages and their effects on in vitro 
dissappearance. Journal of Dairy Science 88: $4414-4425$.

Ferreira, W. M., A. D. P. N. Herrera, C. Scapinello, D. O. Fontes, L. C. Machado, \& S. R. A. Ferreira. 2007. Apparent digestibility of nutrients of simplified diets based on forages for growing rabbits. Arg.Bras.Med.Vet. Zootec. 59: 451-458.

General Laboratory Procedure. 1966. Departement of Dairy Science University of Wisconsin.

Hassanat, F. A. F. Mustafa, \& P. Seguin. 2007. Effects of inoculation on ensiling characteristics chemical composition and aerobic stability of regular and brown midrib milled silages. Anim. Feed Sci. Technol. 139: 125 - 140.

Haustein, S. 2003. Evaluating Silage Quality. http://www1. agric.gov.ab.ca.[12 Maret 2009].

Hiraoka, H., E. Ishikuro, \& T. Goto. 2010. Simultaneous analysis of organic acids and inorganic anions in silage by capillary electrophoresis. Anim. Feed Sci. Technol. 161: 58 $-66$.

Indikut, L., B. A. Arikan., M. Kaplan., I. Gaven., A. I. Atalay, \& A. Kamalak. 2009. Potential Nutritive Value of Sweet Corn as A Silage Crop with or without Corn Ear. Dept. of Animal Science, Faculty of Agriculture. Turkey.

Jarkauskas, J. \& V. Vrotniakiene. 2004. Improvement of grass silage quality by inoculant with lactic bacteria and enzymes. Veterinarija Ir. Zootechnika. T. 28: 79-82.

Kondo, M., N. Naoki, K. Kazumi, \& H. O. Yokota. 2004 a Enhanced lactic acid fermentation of silage by the addition of green tea waste. J. Sci. Food Agric. 84: 728-734.

Kondo, M., K. Kazumi, \& H. O. Yokota. 2004 ${ }^{\text {b }}$. Effect of tea leaf waste of green tea, oolong tea, and black tea addition on sudangrass silage quality and in vitro gas production. J. Sci. Food Agric. 84: 721-727.

Kozelov, L. K., F. Iliev, A. N. Hristov, S. Zaman, \& T. A. McAllister. 2008. Effect of fibrolytic enzymes and an inoculant on in vitro degradability and gas production of low-dry matter alfalfa silage. J. Sci. Food Agric. 88: $2568-2575$.

Marco, O. N. D., M. A. Ressia, S. Arias, M. S. Aello, \& M. Arzadun. 2009. Digestibility of forage silage from grain, sweet and bmr sorghum types: Comparison of in vivo, in situ and in vitro data. Anim. Feed Sci. Technol. 153: 161-168.

McDonald, P., A. R. Henderson \& S. J. E. Heron. 1991. The Biochemistry of Silage. Cambrian Printers Ltd, Aberystwyth, Great Britain.

McDonald, P., R. Edwards, \& J. Greenhalgh. 2002. Animal Nutrition. $6^{\text {th }}$ Ed. New York.

Menke, K. H., L. Raab, A. Salewski, H. Steingab, D. Fritz, \& W. Schneider. 1979. The estimation of digestibility and metabolizable energy content of ruminant feedstuffs from the gas production when they are incubated with ruminant liquor. J. Agric. Sci. 93: 217-222.

Miron, J., E. Zuckerman, G. Adin, R. Solomon. E. Shoshani., M. Nikbachat, E. Yosef., A. Zenou, Z. G. Weinberg., Y. Chen., I. Halachmi, \& D. B. Ghedalia. 2007. Comparison of two forage sorghum varieties with corn and the effect of feeding their silages on eating behaviour and lactation performance of dairy cows. Anim. Feed Sci. Technol. 139: $23-39$.

Miron, J., R. Solomon, G. Adin, U. Nir, M. Nikbachat, E. Yosef, A. Carmi, Z. G. Weinberg, T. Kipnis, E. Zuckerman, \& D. B. Ghedalia. 2006. Effect of harvest stage and re-growth on yield, composition, ensilage and in vitro digestibility of new forage sorghum varieties. J. Sc. Food Agric. 86: 140-147.

Nadeau, E. 2007. Effects of plant species, stage of maturity and additive on the feeding value of whole-crop cereal silage. J. Sci. Food Agric. 87: 789 - 801.

Naumann, C. \& R. Bassler. 1997. VDLUFA-Methodenbuch Band III, Die chemische Untersuchung von Futtermitteln. $3^{\text {rd }}$ ed. VDLUFA-Verlag. Darmstadt, Germany.

Nishino, N. \& E. Touno. 2005. Ensiling characteristic and aerobic stability of direct-cut and wilted grass silages inoculated with Lactobacillus casei or Lactobacillus buchneri. J. Sci. Food Agric. 85: 1882 - 1888.

Nishino, N., H. Harada, \& E. Sakaguchi. 2003. Evaluation of fermentation and aerobic stability of wet brewers' grains ensiled alone or in combination with various feeds as a total mixed ration. J. Sci. Food Agric. 883: 557 - 563

Nishino, N., T. Kawai, \& M. Kondo. 2007. Changes during ensilage in fermentation products, tea catechins, antioxidative activity and in vitro gas production of green tea waste stored with or without dried beet pulp. J. Sci. Food Agric. 87: 1639-1644.

O'Brian, M., P. O'Kiely, P. D. Forristal, \& H. T. Fuller. 2007. Visible fungal growth on baled grass silage during the winter feeding season in Ireland and silage characteristics associated with the occurance of fungi. Anim. Feed Sci. Technol. 139 : 234-256.

Orskov, E. R. \& M. Ryle. 1990. Energy Nutrition in Ruminant. London: Elseivier.

Rizk, C, A. F. Mustafa, \& L. E. Phillip. 2005. Effects of inoculation of high dry matter alfalfa silage on ensiling characteristics, ruminal nutrient degradability and dairy cow performance. J. Sci Food Agric. 85 : 743-750.

Tafaj, M., Q. Zebeli, B. Junck, H. Steingass \& W. Drochner. 2005. Effects of particle size of a total mixed ration on in vivo ruminal fermentation patterns and inocula characteristics used for in vitro gas production. Anim. Feed Sci. Technol. 123-124: 139-154.

Tessema, Z. \& R. M. T. Baars. 2004. Chemical composition, in vitro dry matter digestibility and ruminal degradation of Napier grass (Pennisetum purpureum (L.) Schumach.) mixed with different levels of Sesbania sesban (L.) Merr. Anim. Feed Sci. Technol. 117: 29 - 41.

Titterton, M. 2000. Grass and legume silages in the tropics. In: Mannetje, L.T. Silage Making in the Tropics with Particular Emphasis on Smallholders. Proceedings of the FAO Electronic Conference on Tropical Silage 1 September to 15 December 1999.

Wang, C., Q. Liu, W.J. Huo, W.Z. Yang, K.H. Dong, Y.X. Huang, \& G. Guo. 2009. Effects of glycerol on rumen fermentation, urinary excretion of purine derivatives and feed digestibility in steers. Livestock Science 121: 15-20.

Wannapat, M., R. Pilajun, \& P. Kongmun. 2009. Ruminal ecology of swamp buffalo as influenced by dietary sources. Anim. Feed Sci. Technol. 151: 205-214.

Weissbach, F. \& H. Honig. 1996. Über die Vorhersage und Steuerung des Garungsverlaufs bei der Silierung von Grunfutter aus extensivem Anbau. Landbauforschung Volkenrode, 1: 10-17, Germany.

Zamudio, D. M., J. M. Pinos-Rodríguez, S. S. González, P. H. Robinson, J. C. García, \& O. Montañea. 2009. Effects of Agave salmiana Otto Ex Salm-Dyck silage as forage on ruminal fermentation and growth in goats. Anim. Feed Sci. Technol. 148: 1-11. 